\title{
POSSIBILITIES OF CONSTRUCTION OF MULTI-FUNCTIONAL FLOOD POOLS IN THE MOUNTAINS OF PODKARPACIE REGION, POLAND
}

\author{
JAN JAREMSKI \\ Department of Geotechnics and Hydraulic Engineering, Faculty of Civil and Environmental Engineering, \\ Rzeszów University of Technology, ul. Powstańców Warszawy 12, 35-959 Rzeszów, Poland, \\ phone: +48 178651342, fax: +48 178651670, e-mail: jjaremsk@prz.edu.pl
}

\begin{abstract}
The proposed concept of building storage reservoirs in mountainous Podkarpacie area will decidedly influence flood situation of this region and will decrease the extent of losses caused by the arising of landslides. A suitable geological structure allows for cheap construction of reservoirs. Dislocations and fault fissures are filled with weathering materials because of their mineralogical structure, i.e., swelling minerals cause self-sealing of the bottom. A lack of water-bearing layers eliminates uncontrolled outlet of water to the ground.
\end{abstract}

\section{INTRODUCTION}

The proposed concept of building storage reservoirs in mountainous Podkarpacie area will decidedly influence flood situation of this region and will decrease the extent of losses caused by the arising of landslides. A relatively favourable geological structure supports exceptional treatment of Bieszczady as regards the location of reservoirs. The outside part of the massif is built of flysch formations, i.e., sandstones, shales, mudstones. Eluvia of these stones most often occur as silts or silty clays at the surface layer. Flowing in interpore spaces is difficult because of their small dimensions. Moreover, these spaces are filled with weathered clayey fraction which is very sensitive to shrinkage and swelling. It reduces the flysch water storage capacity, even to zero. The water storage capacity gets worse with depth of layers occurrence. Recourses of ground waters are slight; there is lack of water-bearing layers.

The climate variations have been observed lately. They are accompanied by an increase of the weather dynamics and unusual intensity of extreme phenomena. Precipitations are very intense and they are accompanied by landslides and mud avalanches, or long-lasting droughts. A lack of suitable retention causes a fast flow of discharge water to the seas. Mineralogical composition of rocks or their eluvia occurring in the area considered is usually not taken into account while forecasting such phenomena. Colloidal activity, a state of colloidal bonding and crystallization strongly influence formation of avalanches, strength of the mixtures and reversibility of their reactions with participation of aluminosilicates (illite, montmorillonite). 
Polish water resources are rather poor in comparison with other European countries, with $1600 \mathrm{~m}^{3}$ falls to one person in a typical year; in a dry year, below $1450 \mathrm{~m}^{3}$ [1]. In Spain, such number is twice as high, and for all Europe this number equals $4500 \mathrm{~m}^{3}$. Retention ability of Polish reservoirs equals $6 \%$ of the mean flow of the surface water per year. Moreover, it does not prevent against periodical excess of deficit of water. Our water resources vary in different seasons and their distribution is not uniform. The Podkarpacie region, especially its mountain part, belongs to the regions where the water resources are the most poor. Only $20 \%$ of all the underground water of that region occur in its mountain part. In this region there is a lack of rich aquiferous layers because of an unique geological structure, i.e., the laminar Carpathian flysch. It is water-permeable (there are no faults and dislocations), so in this region there are very good conditions for small flood pools. Such conditions allow for high surface flows which can be significantly slowed down owing to renaturization of the flows and so-called "small retention". The program of "small retention" gives the best results in mountain and forest areas, for example the Bieszczady mountains in the south of Poland. "Small retention" satisfies most requirements connected with ecological methods of water economics, and if correctly realized, this can help in improvement of natural values of ecosystems [10].

The Podkarpacie region belongs to the mountain range of the Carpathian arc and the fall before the Carpathians. The region is very diversified considering its configurations and geological structure. Such diversification influences hydrography, climate, soils, flora and fauna, etc. In the region considered there is a line of the watershed between catchments of the Baltic Sea and the Black Sea. Intense precipitations in the summer are very important for the idea of construction of flood pools. The mountain part of the region belongs to the Carpathian climate with thermal conditions varying depending on the site height.

Geological and hydrogeological conditions of the region in its mountain part are really suitable for the flood pools. The eastern Carpathians are built of flysch formations, weathered in their top layer. The eluvia usually occur as dust or silt clays. The external part of the massif contains flysch formations (Fig. 1), i.e., sandstone, mudstone, menillites, etc. [13].

The Bieszczady mountains are the area where there are very good conditions for the reservoirs considered because of favourable tectonics and its effects. From the tests carried out in the Podkarpacie region it appears that the eluvia occurring under the surface are of a high volume, and from mineralogical tests it results that they are suitable for location of reservoirs because they guarantee the maximum tightness. Thus, construction of small earth dams or rock-fill dams probably will not require application of additional sealing elements. The eluvium of suitable parameters will play this role. The eluvia in the layers located just under the surface usually occur as dust or dust clays. 


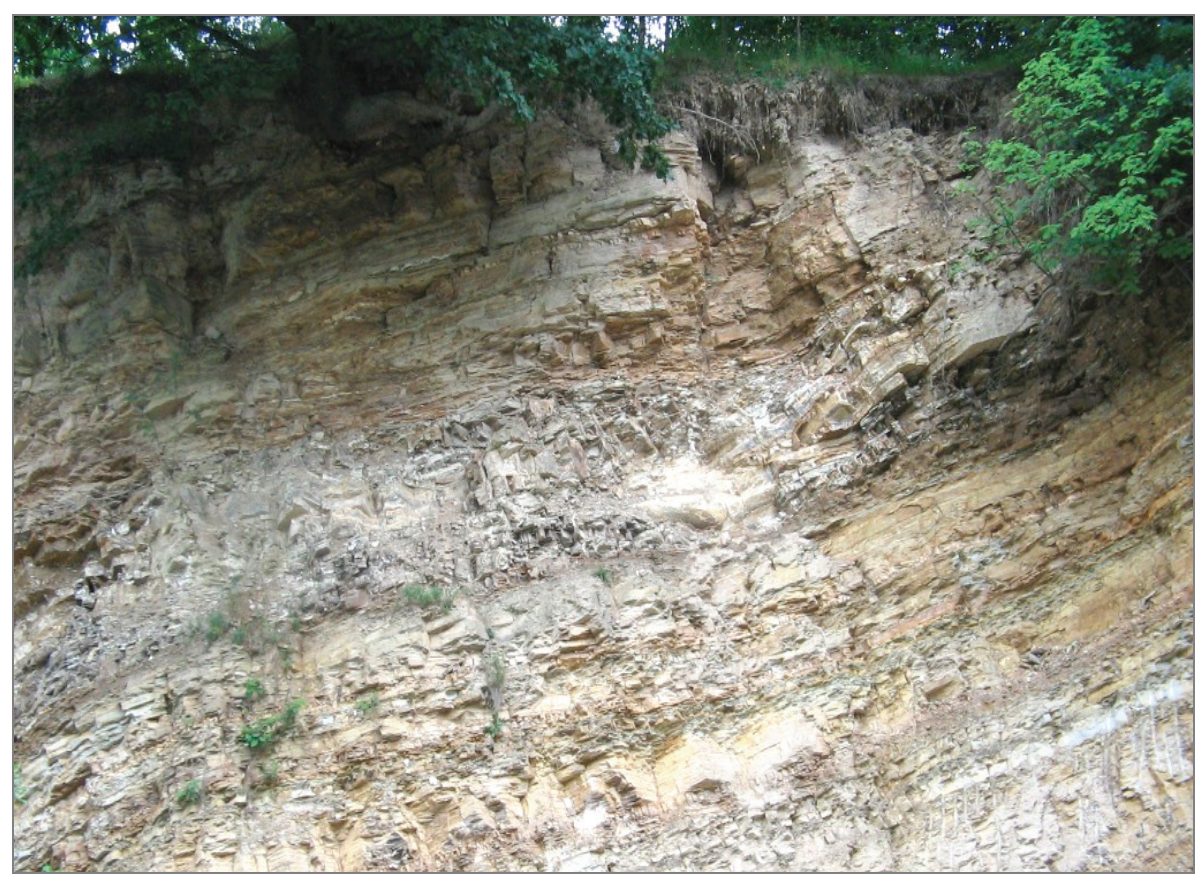

Fig. 1. Outcrops of the Carpathian flysch

Generally speaking, in the flysch formations of the Podkarpacie region there are no advanced aquiferous layers. The minimum surface permeability is also the effect of mineralogical structure of the surface layers. Under moderate swelling, illite minerals seal the site surface and increase intensity of the surface flow. In consequence, even relatively low precipitations cause a flood situation at many water-courses and rivers in the Poskarpacie region. Thus, construction of multi-functional pools of small retention on the limited areas protects the water-courses of the Podkarpacie region against the results of floods. The proposed idea increases pure water resources, influences beauty of the region. It also changes geotechnical conditions and improves stabilization of slopes, protects against landslides.

The proposed idea seems to be reasonable because in 1995 in Japan 360 such reservoirs were built in the mountains, and the country was protected against floods. At the same time, suitable amount of water was delivered for rice growing (Japan is an important exporter of rice at present).

Let us note that the pools considered are located in the mountains, and the cofferdams baffling the valleys are made of soil concrete because of a large amount of montmorillonite in the rock eluvia. In the past, in Andalusia the Moor engineers built the reservoirs used for the purposes of agriculture, and this part of Spain developed very quickly. 
In the Podkarpacie region there are unique hydrogeological conditions. About $20 \%$ underground waters occur in the mountain region, and this results from the lack of advanced aquiferous layers. The greater part of underground waters occurs in the reservoir between the towns Dębica-Rzeszów-Stalowa Wola. The underground water in this area strongly depends on hydrogeological environment, i.e., on its composition and dissolved substances being in contact with water, also on conditions under which this activity takes place. Analysis of the water composition allows us to forecast composition of surface water in the flood pools. Investigation of such reservoirs as Solina and Myczkowce proved that their water was of a good quality. Let us remember that the proposed pools should be supplied by water flowing from the eastern Carpathians being an enclave of unique environmental conditions.

Water-bearing character of the flysch rocks is connected with their slots - it results from their low porosity, i.e., from 0.02 to 0.1 . The flow in the interporous spaces is difficult because of their small dimensions; moreover, they are filled with the weathered illite fraction, susceptible to shrinkage and swelling, decreasing water absorbability of the flysch, sometimes to zero. Water absorbability gets worse as the depth of layer deposits rises. Resources of underground water are very low, there are no waterbearing layers. Water is stopped and occurs only in the cracked rocks. Under such conditions, precipitation waters can easily flow to the water-courses, and next to the fall before the Carpathians where they supply the reservoir of underground waters. From that reservoir they flow through the underground gutters to the basin of the Dniestr River. Minimal surface permeability is also an effect of mineralogical structure of surface layers, i.e., illite and smectite minerals. Because of swelling, these minerals seal the surface and increase intensity of the surface run-off. In consequence, even relatively small amounts of precipitations cause floods by many rivers and watercourses of the Podkarpacie region.

Climate variation causes serious rainstorms which are very dangerous for inhabitants of the Podkarpacie region. Such a storm took place on the 26th July 2005 near the locality of Zagórz. Some villages were flooded in a very short time. The above mentioned example of Japan also proves that the proposed solution seems to be sensible.

\section{THE PREDICTED KINDS OF FLOOD POOLS}

Rational management of water resources in the Podkarpacie region requires minimization of their variation in time and space (periods of drought and flood). Thus, retention must be developed in the area of the basin. Construction of small multifunctional pools is recommended. In management of each pool one function is usually dominating (flood protection, touristic, ecological or energy function and so on), and other tasks are assigned to that main function. In practice, there are pools satisfying two or three main economic tasks at the same time depending on local needs. 
There is no one official classification of flood pools. So-called "small retention" includes all the microreservoirs, and small pools positively influencing the environment [8]. Small pools are usually of total volume to 0.1 million $\mathrm{m}^{3}$ and the maximum swell height $5 \mathrm{~m}$. They are built one by one, or in a cascade system [13]. The whole cascade is usually used for energetic purposes. The systems of small retention pools are proposed instead of one big reservoir. In the Bieszczady mountains there are many river valleys (Figs. 2 and 3), which are good places for the proposed flood pools. In the past many people lived in those valleys, at present they are uninhabited.

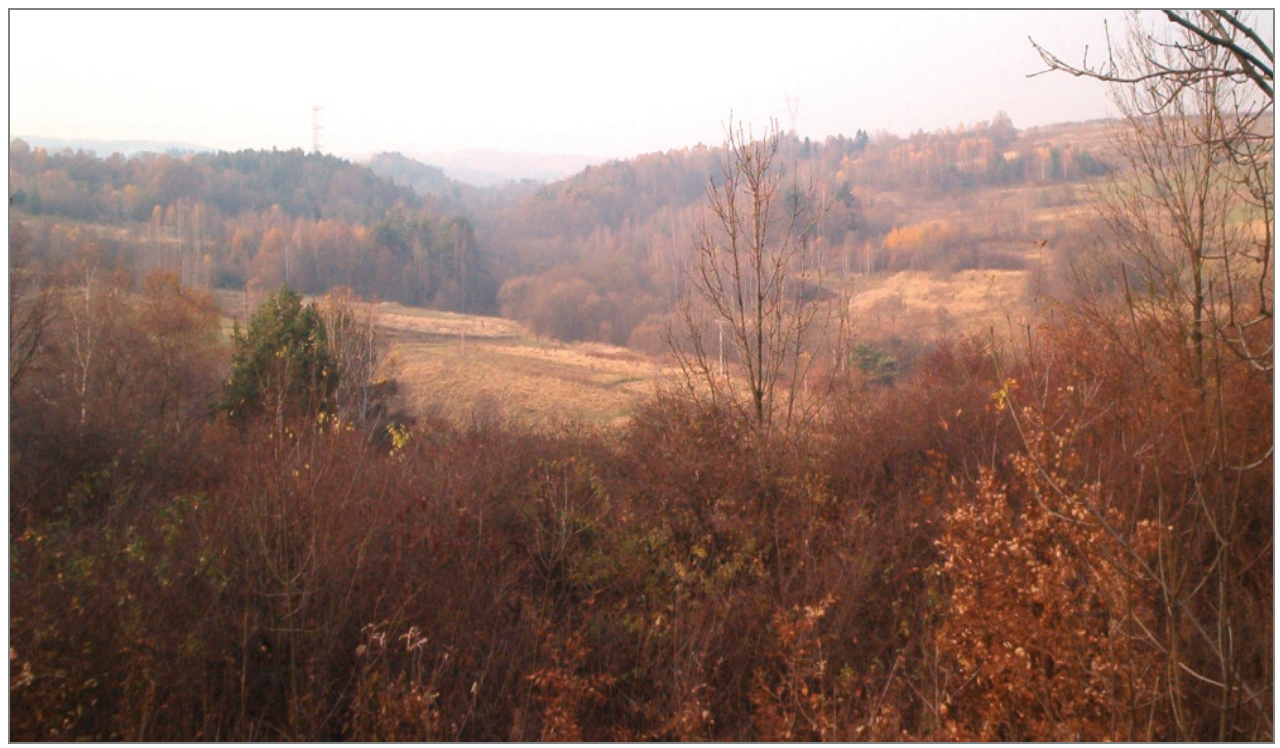

Fig. 2. An exemplary site for a reservoir in the Bieszczady mountains

According to the proposed concept, reservoirs - depending on their location - can be flood pools, equalizing tanks, they can also be auxiliary reservoirs near big flood pools [3]. Some reservoirs should play the role of flow reservoirs formed as a result of partition of water-courses. Dry reservoirs are also provided as anti-flood protection. They will accumulate the flowing eluvium or organic products.

In the region considered, intense precipitations, big slopes of the ground and the flysch substrate cause intense run-off of the weathered flysch layer, sometimes being like an avalanche. The rubble occurring in the reservoirs and flumes of water-courses causes that they become more and more shallow. Hence construction of dry reservoirs. In the area considered there are unusual conditions of flysch weathering, especially biological weathering. Such conditions are the result of rich afforestation. In Poland, the forests cover $28.4 \%$ of the area. The Podkarpacie region has got many forests $(35.9 \%)$. Generally speaking, in the region considered it will be possible to plan dry 
reservoirs which will accumulate the flowing weathered eluvia or organic products. Such places will be the programmed enclave of intense development of flora and fauna, we can also expect favourable humus processes.

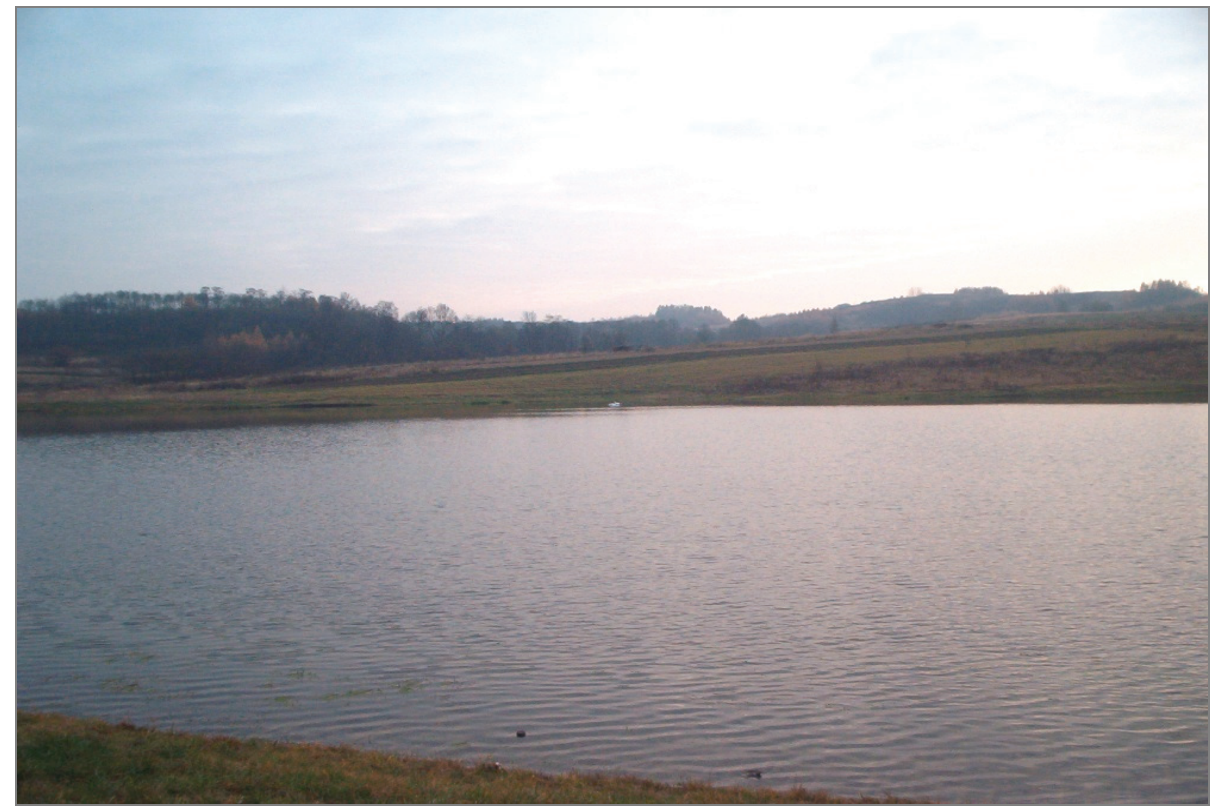

Fig. 3. The existing reservoir in the village of Blizne

The Rzeszów reservoir can be a good model example of influence of the proposed reservoirs on the natural environment. The Rzeszów reservoir is an artificial water reservoir on the Wisłok river built in 1971 in order to provide water intakes for Rzeszów and protect the city against floods, Fig. 4. Water from the reservoir flooded sites of the old strip mines of sand and gravel. At first, the reservoir was prolate and its area was about 90 ha. The alluvial products of the flysch weathering are the main reason for the reservoir becoming more and more shallow. After the 1997 flood very intense silting up of the Rzeszów reservoir was observed. At present, a great part of the primary area of that reservoir is overgrown. The reservoir and the area around it has became a rich and interesting natural environment.

Let us note that the existing, designed and planned reservoirs are provided mainly in the higher parts of the Podkarpacie region, according to the valid plans of the region managemet and documentation of the regional Board of Land Melioration and Water Devices in Rzeszów. These ideas do not include management of rubble and other products of flysch weathering (especially important under the expected weather conditions) accumulated in the river and reservoir flumes. Moreover, waters of these reservoirs increase accumulation of the underground water reservoir. From there they 
flow through underground passages to the basin of the Dniestr river. Thus, resources of Polish underground waters become poorer.

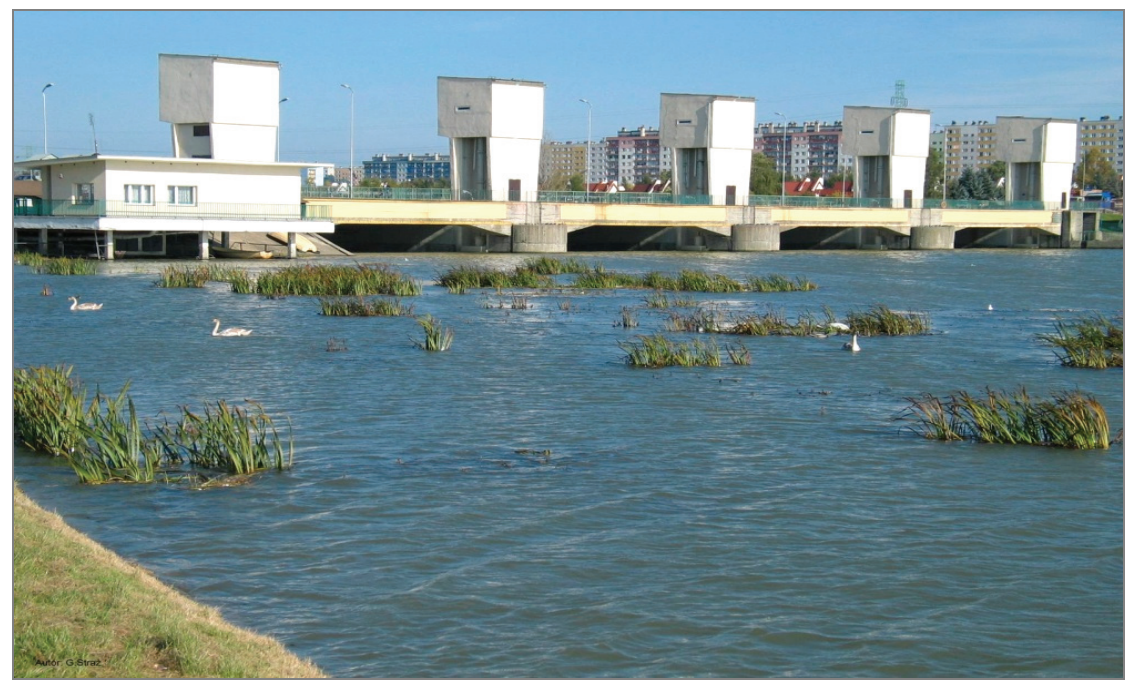

Fig. 4. Rzeszów reservoir

\section{APPLICATION OF FLYSCH ELUVIA FOR CONSTRUCTION OF COFFERDAMS}

From the investigations on landslides in the Podkarpacie area it appears that the eluvia existing under the site surface are of a great thickness. From mineralogical tests it results that such eluvia are very good for location of reservoirs because they provide the maximum tightness. Thus, construction of small earth dams will not require additional sealing elements. This role should be played by a layer of eluvium of suitable parameters.

Experience gained during investigations on marl eluvia as well as the elaborated test methods were applied for investigation of the Carpathian flysch and dust soils occurring in the river terraces, grounds of loess massif, illite clays and baidelite clays. These grounds are susceptible to moisture changes accompanied by shrinkage and swelling as well as petrification. This property is strictly connected with the presence of illite in mineralogical composition of the media considered. Even a very small amount of that mineral influences joints of the basic minerals.

The samples prepared of eluvium shales were tested and next the results obtained were compared with the results obtained for the samples from river valleys treated as the accumulated sediment of the flysch eluvium [5]. The tests were carried out in order to estimate usability of flysch eluvia for construction of cofferdams by identification 
of clayey minerals. Differentiation of these minerals is important because the contents of smectite groups exerts an unfavourable influence on the setting and hardening of ground concrete [12]. As for the ground media considered, their basic geotechnical parameters were tested and special attention was paid to swelling tests allowing clayey minerals to be distinguished. Before the swelling tests, physical, chemical and strength tests as well as mineralogical tests of the media considered were carried out [7], [9]. Recognition of the grounds was based on chemical and mineralogical compositions by means of fluorescence, X-ray difractommetry and scanning microscopy. Moreover, derivatographic analysis was made. Recognition of microstructure of the clays with so-called hidden swelling parameter was carried out by means of scanning microscopy [4]. The tests of chemical composition show the presence of potassium which occurs only in illite. This was proved by tests performed by means of the scanning electron microscope (SEM).

The tests of flysch swelling, swelling clay or the media with so-called hidden swelling parameter used the method described in the patent No. 196795, [11]. This method allows for cheap tests of flysch eluvia and estimation of their usability. Identification of illite in the flysch eluvium allows it to be qualified as a material for construction of cofferdams because of moderate shrinkage and swelling as well as favourable petrification and sealing properties. Moreover, the proposed tests could help in selection of places for reservoir location taking a proper tightness of the ground into account.

The presence of illite being an aluminosilicate responsible for eluvium petrification allows for application of flysch chips and flysch eluvia for construction of earth cofferdams sccording to the proposed construction of multi-functional pools in the Bieszczady mountains [3]. In Japan, the flood pools were located in the mountains and the cofferdams in the valleys were made of ground-concrete. The eluvia occurring in Japan contain montmorillonites, so formation of cofferdrams is difficult because it is necessary to add much cement to the eluvia. It is also necessary to take care of ground-concrete because of the formation of scratches caused by shrinkage of montmorillonite [12].

Construction of cofferdrams using flysch chips and flysch eluvia is considered for each reservoir in Bieszczady, depending on its geological structure. Of course, a suitable amount of clayey minerals for petrification and sealing is necessary. If there are no enough illite minerals in the eluvium, we must consider a solution using geotextiles and sealing foils for cofferdrams, and materials offered by such firms as Tensar International Corporation, Ten Cate Geosynthetics and Geobrugg.

At present, the author is engaged in works connected with the causes of mud avalanches formation, and proposes tests on determination of the eluvium areas especially susceptible to formation of mud avalanches in the mountains sites.

In such cases, hydraulic conditions and influence of mineralogical composition should be taken into account. Tests of susceptibility of soft rocks to formation of mud avalanches could be limited to drawing of eluvium samples occurring at the slope. The 
samples should be subjected to swelling tests by means of the method given in the patent and in some previous papers [4], [6]. This simple method allows us to identify clayey minerals responsible for swelling, occurring in the rocks. During the tests we made use of the presence of endothermic maxima - the temperature points at which the heated sample loses contents of bound water. The author found that minerals from the groups of monmorillonite and illite (causing swelling) lost the water at a temperature up to 200 degrees, and kaolinite - at 600 degrees. Thus, the comminuted eluvium sample prepared to the standard swelling test and free from water, subjected to the swelling test manifests swelling up to tens percent. Under such conditions, the kaolinite sample swells up to some percent. Let us remember that montmorillonites soak to $700 \%$, while kaolinite soaks to $90 \%$.

The test considered informs us about amounts and kinds of swelling minerals at the point of sampling. Thus, we get also the data concerning ability of the tested rock medium to water stoppage and moisture degree, as well as the maximum moisture occurring under natural conditions. After swelling, the sample moisture is the maximum moisture, under which we get the worst numerical values of the strength parameters. Under such conditions, landslides are possible. In our analysis, soft rocks are treated as mixtures containing much clayey minerals. In the case of the occurrence of greater contents of montmoryllonite, greater amount of moisture is present and it is accompanied by fluidization and formation of mud avalanches. Similarly, the content of the swelling minerals in higher parts of mountains causes their being collected in the rock slots. Then, the possibility of landslides and rock falls increases. Simple analyses and tests according to the swelling tests discussed allow us to identify sites which can be easily subjected to mud avalanches and rock falls. Such information is very useful for the site management.

\section{CONCLUSIONS}

A suitable geological structure allows for cheap construction of reservoirs. Dislocations and fault fissures filled with weathering materials because of their mineralogical structure, i.e., swelling minerals cause self-sealing of the bottom. A lack of waterbearing layers eliminates uncontrolled outlet of water to the ground.

Distinct improvement of protection against floods is an advantage of the proposed solution (see the aforementioned solution in Japan). At present, intense precipitations are transported to water-courses and rivers because they cannot percolate to the ground (it is favourable for reservoir structure).

Water supply for inhabitants of a given region and water collecting in reservoirs can be very important in the future. Large amount of water of high quality should be a valuable good. Water resources could influence future development of many regions. 
Construction of the reservoirs considered is rather cheap because it is possible to introduce unified earth cofferdrams using ground-concrete as a constructional material. Some reservoirs could be used in energetics.

\section{REFERENCES}

[1] Bogacz-Rygas M., Aspekty ekologiczne stosowania nowych rozwiqzań odprowadzania wód opadowych i ich zagospodarowanie (in polish), Wavin Metalplast-Buk, Kielce, 2007.

[2] JAREMSKI J., Influence of physical and chemical processes occurring in eluvium of the Opole marls and their influence on the geotechnical parameters, Proceedings of the 7th International Congress IAEG, Lisboa, A.A. Balkema, 1994, 859-868.

[3] JAREMSKI J., O niektórych aspektach budowy wielofunkcyjnych zbiorników retencyjnych $w$ części górzystej województwa podkarpackiego. Cywilizacja i żywioły (in polish), seria: Monografie Instytutu Meteorologii i Gospodarki Wodnej, Warszawa, 2007.

[4] JAREMSKI J., Proposal for a method determining value of the maximum swelling of soil by example of the Opole marls eluvium and illite clays. Proc. of 8th Int. Cong. on Rock Mechanics, A.A. Balkema, Tokyo, 1995.

[5] JAREMSKI J., The influence of changes of weathering water content on the formation of landslides in the Carpathian Flysch, Proc. of 9th Australia New Zealand Conference on Geomechanics, Auckland - February 2004, New Zealand Geotechnical Society Inc.

[6] JAREMSKI J., The influence of physical and chemical processes occurring in the weathered Opole marls on the geotechnical parameters, Publishing House of Rzeszów University of Technology, 2005, 98.

[7] JAREMSKI J., Creep property of Opole marls weathering on the base of the model laboratory research and the research "in situ", Proceedings of the 7th International Congress on Rocks Mechanics, A.A. Balkema, Aachen, 1991, 269-273.

[8] JAREMSKI J., Aspekty geotechniczne w ochronie zasobów wodnych województwa podkarpackiego, Inżynieria Morska i Geotechnika (in polish), No. 1, Gdańsk, 2010.

[9] JAREMSKI J., Influence of moisture changes on physico-chemical processes and geotechnical parameters in soft rocks, Studia Geotechnica et Mechanica, 2010, Vol. XXXII, No. 1, 1-22.

[10] MIODUSZEWSKI W., Mała retencja w lasach elementem ksztattowania i ochrony zasobów wodnych, Studia i Materiały Centrum Edukacji Przyrodniczo-Leśnej, R. 10, Zeszyt 2 (18) / 2008.

[11] Patent Politechniki Rzeszowskiej nr 196795: Sposób określania zdolności do pęcznienia gruntów i skat (in polish).

[12] WAKIZAKA Y. et al., Influence of montmorillonite group Bering aggregates on concrete, 7th International IAEG Congress, A. A. Balkema, 1994, 3285-3294.

[13] Zabuski L., Thiel K., Bober L., Landslides in Polish Carpathian Flysch (in polish), IBWN PAN, Gdańsk, 1999, 172. 